\title{
Frequency and Presentation of Autoimmune Hepatitis and Type of Autoantibodies among Yemeni Patients Attending Private Medical Clinic in Aden Yemen
}

\author{
OSAM S. ABDO GABALI, M.D. \\ The Department of Internal Medicine, Faculty of Medicine and Health Sciences, Aden University, Yemen
}

\begin{abstract}
Background: Autoimmune hepatitis is a complex disease that represents a challenge in diagnosis and management due to the diversity of the clinical presentation, now recognized as a relatively rare disease predominantly affecting females.

Aim of Study: This study aimed to describe the frequency and presentation of autoimmune hepatitis and type of autoantibodies among patients who attend a private clinic in Aden Yemen.
\end{abstract}

Patient and Methods: A prospective study carried out in a private clinic over a period of two years, from June 2016 to June 2018, all of 60 patients had raised liver enzymes and Antinuclear Antibodies (ANA), Anti-Smooth-Muscle Antibodies (ASMA) titers 1:80 or above upper limit, Anti Liver Kidney Microsomal (LKM-1). Titer 1:40 or above upper limit, and IgG more than 10 times of normal have been included in this study, all patients rejected liver biopsy.

Results: 60 subjects were recruited into study. The sex distribution showed a prominence of female gender $(63 \%)$ versus $(36 \%)$ being male. Residency distribution revealed that, the majority of our patients came from shabwa governorate $(53.3 \%)$. The frequency of chronic hepatitis is $40 \%$ while each of acute hepatitis and liver cirrhosis constituted $30 \%$ of patients, antinuclear antibodies was elevated in $73.3 \%$ antismooth-muscle antibodies in $25 \%$ while anti liver kidney microsomal antibody was elevated only in $1.6 \%$.

Conclusion: Autoimmune hepatitis frequency, presentation and type of autoantibodies among Yemeni patients do not remarkably differ from studies carried out world wide.

Key Words: Autoimmune hepatitis - Antinuclear antibodies - Anti-smooth-muscle antibodies.

\section{Introduction}

THE first to describe a chronic form of hepatitis in young women was Jan Waldenström in 1950 [1] Later, the disease was associated with other au-

Correspondence to: Dr. Osam S. Abdo Gabali, The Department of Internal Medicine, Faculty of Medicine and Health Sciences, Aden University, Yemen toimmune diseases and was termed "lupoid hepatitis" because of the presence of antinuclear antibodies and lupus erythematous cells [2]. These observations led to the idea that the foundation of this disease was a loss of immunological tolerance. The term Auto Immune Hepatitis (AIH) in its current meaning was introduced by Mackay and colleagues in 1965 when the concept of autoimmunity was acknowledged at an international meeting [3]

Autoimmune hepatitis is now recognized as a relatively rare chronic inflammatory liver disease predominantly affecting females in which a loss of tolerance against hepatic tissue is assumed. Based on the type of serum autoantibodies, Autoimmune hepatitis can be subdivided into two types: Type 1 autoimmune hepatitis, identifiable by Antinuclear Antibodies (ANA) and/or antiSmooth Muscle Antibodies (SMA), and type 2 autoimmune hepatitis, predominantly found in children and defined by antibodies against Liver Kidney Microsomal type 1 (anti-LKM-1) or for anti-liver cytosol type 1 antibodies $[4,5]$

Autoantibodies are the hallmark of autoimmune hepatitis and can constitute an important part of the diagnostic work up. The classic antibodies associated with autoimmune hepatitis are Antinuclear Antibodies (ANA), Anti-Smooth-Muscle Antibodies (ASMA) and Anti Liver Kidney Microsomal (LKM-1). About $70 \%-80 \%$ of autoimmune hepatitis patients have significant titers $(\geq 1: 40)$ of ANA or ASMA and overall $3 \%-4 \%$ have anti LKM1 , while up to $20 \%$ are seronegative for these antibodies.

Autoantibody-negative autoimmune hepatitis may be associated with an autoantibody outside the conventional battery; it may have a signature 
autoantibody that is still undiscovered, or its characteristic autoantibodies may have been suppressed or have a delayed expression. The pathogenic mechanisms are presumed to be identical to those of classical disease. Autoantibody-negative autoimmune hepatitis is an infrequent but treatable disease that must be considered in unexplained acute and chronic hepatitis [7].

Autoimmune hepatitis is a complex disease that represents a challenge in diagnosis and management due to the diversity of the clinical presentation, wide spectrum of the disease and variable response to treatment [8].

The etiology of autoimmune hepatitis has not been completely elucidated, but immunogenetic background and environmental parameters may contribute to its development. The most important genetic factor is Human Leukocyte Antigens (HLAs), especially HLA-DR, whereas the role of environmental factors is not completely understood. Immunologically, disruption of the immune tolerance to autologous liver antigens may be a trigger of autoimmune hepatitis [9].

The diagnosis of autoimmune hepatitis is usually suspected when ongoing hepatocellular inflammation cannot be explained on the basis of chronic viral infection, alcohol consumption, or exposure to hepatotoxic medications or chemicals. As such, it is often a diagnosis of exclusion [10].

\section{Aims of work:}

The goals of this study are to describe the frequency and presentation of autoimmune hepatitis and type of autoantibodies among Yemeni population.

\section{Material and Methods}

This was a prospective study carried out in a private clinic in Aden-Yemen, over a period of two years, from June 2016 to June 2018, of all patients who had raised liver enzymes and Antinuclear Antibodies (ANA), or Anti-Smooth-Muscle Antibodies (ASMA) titers 1:80 or above upper limit, Anti Liver Kidney Microsomal (LKM-1). Titer 1:40 or above upper limit, and IgG more than 10 times of normal have been included in this study, all patients rejected liver biopsy. or more, Anti Liver Kidney Microsomal (LKM-1).

Patients were excluded if they have positive viral hepatitis serology, alcohol consumption abnormal serum ceruloplasmin, using medications or herbal therapy, which affecting liver functions. acute presentation as defined by abrupt onset of symptoms together with significant rise in liver function test, while chronic presentation used to describe disordered liver function lasting for six months or more, diagnosis of liver cirrhosis was based on clinical decompensation, and radiological findings of contour nodularity, coarse and heterogeneous texture.

Computer analyzed the data and because the population was small, the result was calculated manually, and presented as mean, percentage and tables as appropriate.

Ethical consideration. Verbal informed consent was obtained from all participating subjects. The study design was approved by the research and ethics committee in the Faculty of Medicine University of Aden.

\section{Results}

60 subjects were recruited into study. Their age ranged from 19 to 45 years with a mean value \pm SD (32 \pm 13$)$ years.

The Sex distribution in (Table 1) showed a prominence of female gender (63\%) versus $(36 \%)$ being male.

Table (2) showed residency distribution revealed that, the majority of our patients came from shabwa governorate $(53.3 \%)$.

Table (3) showed that the frequency of chronic hepatitis in $40 \%$, acute hepatitis in $30 \%$ and liver cirrhosis in $30 \%$.

Table (4) revealed that antinuclear antibodies percentage is $73.3 \%$ anti-smooth-muscle antibodies is $25 \%$ while anti liver kidney microsomal antibody is $1.6 \%$.

Table (1): Sex distribution.

\begin{tabular}{lcc}
\hline Sex & No. of patients & $\%$ \\
\hline Female & 37 & 61.6 \\
Male & 23 & 38.3 \\
\hline
\end{tabular}

Table (2): Residency distribution.

\begin{tabular}{lcl}
\hline Residency & No. of patients & $\%$ \\
\hline Shabwa & 32 & 53.3 \\
Dalae & 12 & 20 \\
Aden & 9 & 15 \\
Lahg & 7 & 11.6 \\
\hline
\end{tabular}


Table (3): Clinical presentation.

\begin{tabular}{lcc}
\hline Clinical presentation & No. of patients & $\%$ \\
\hline Chronic presentation & 24 & 40 \\
Acute presentation & 18 & 30 \\
Liver cirrhosis & 18 & 30 \\
\hline
\end{tabular}

Table (4): Type of autoantibody.

\begin{tabular}{lcc}
\hline Type of autoantibody & Frequency & $\%$ \\
\hline Antinuclear antibodies & 44 & 73.3 \\
Anti-smooth-muscle antibodies & 15 & 25 \\
Anti-liver kidney microsomal antibody & 1 & 1.6 \\
\hline
\end{tabular}

\section{Discussion}

60 patients were seen in a private clinic. Their age ranged from 19 to 45 years with a mean value $\pm \mathrm{SD}(32 \pm 13)$ years.

Autoimmune hepatitis can occur at any age but often diagnosed at age of 40-60 and it affects women more than men with female to male ratio of 3-4:1 [4]

Abdul Rahman et al., in their retrospective study clinical presentation, treatment outcome and predictors of severity in autoimmune hepatitis in Riyadh, Saudi Arabia revealed mean age was 36.2 \pm 16.8 years. This is a much closer to the age distribution of this study [11,12].

Median age in our study is less than that mentioned in an article titled by current epidemiology and clinical characteristics of autoimmune liver diseases in South Korea which shown a median age of 56 years and female-to male ratio of 6.4

The sex distribution showed a prominence of female gender $(63 \%)$ versus $(36 \%)$ being male, while a study for epidemiology and clinical characteristics of autoimmune hepatitis in the Netherlands. By Van Gerven et al., reported 78\% females

Demographic distribution shown that, the majority of our patients came from shabwa governorate (53.3\%), Dalae (20\%), Aden (15\%) Lahg (11.6\%).

Chronic hepatitis was the most observed in this study in $40 \%$ of patients while acute hepatitis was seen in $30 \%$.

This study agrees with Abdurrahman et al., [11] which found that, presentation was chronic in $37.7 \%$, and acute in $30.7 \%$, liver cirrhosis seen in
$30 \%$. Of recruited patients in this study, this result nearly similar to the percentage $(28.8 \%)$ reported in Abdurrahman et al., [11], and higher than percentage $(22.7 \%)$ and $(23 \%)$ reported in Korean patients studied by Kim and his colleagues [15], and Sook-Hyang [13] respectively. And higher than percentage $(12 \%)$ in the Netherlands patients as studied by Van Gerven et al., [14] .

Liver cirrhosis was more prevalent in autoimmune hepatitis patients, it was reaching $(50 \%)$ of recruited patients in the European study of the natural history of autoimmune hepatitis presenting with jaundice [16].

In this study, $73.7 \%$ of patients have antinuclear antibodies, close to results demonstrated by Nicole et al., [6] which showed that antinuclear antibodies present in $70 \%-80 \%$ of autoimmune hepatitis patients, while anti-smooth-muscle antibodies and anti-liver kidney microsomal antibody in this study constituting $25 \%$ and $1.6 \%$ respectively, less than percentage mentioned in Nicole et al., study [6] .

\section{References}

1- WALDENSTROM J.: Liver, blood proteins and nutritive protein, Dtsch Z Verdau Stoffwechselkr., 9: 113-9, 1953.

2- COWLING D.C., MACKAY I.R. and TAFT L.I.: Lupoid hepatitis. Lancet, 271: 1323-6, 1956.

3- MACKAY I.R., WEIDEN S. and HASKER J.: Autoimmune hepatitis. Ann. N. Y. Acad. Sci., 124: 767-80, 1965.

4- MANNS M.P., CZAJA A.J., GORHAM J.D., KRAWITT E.L., MIELI-VERGANI G., VERGANI D. and VIERLING J.M.: Diagnosis and management of autoimmune hepatitis. American Association for the Study of Liver Diseases Hepatology, 51: 2193-213, 2010.

5- CZAJA A.J.: Current and future treatments of autoimmune hepatitis. Expert Rev. Gastroenterol. Hepatol., 3: 269-91, 2009.

6- NICOLE M.F. VAN GERVEN, YNTO S. De BOER, CHRIS J.J. MULDER, CARIN M.J. VAN NIEUWKERK and GERD BOUMA (2016 May). Auto immune hepatitis, World J. Gastroenterol., 21; 22 (19): 4651-466, 2016.

7- CZAJA 8 A.J. (Mar). Autoantibody-negative autoimmune hepatitis. Dig. Dis. Sci., 57 (3): 610-24, 2012.

8- FALLATAH H.I. and AKBAR H.O.: Autoimmune liver disease-are there spectra that we do not know? Comp. Hepatol., 10: 9, 2011.

9- AIZAWA Y. and HOKARI A.: Autoimmune hepatitis: Current challenges and future prospects. Clinical and Experimental Gastroenterology; Volume: 10 Pages 9-18, 2017.

10- MAKOL A., WATT K.D., CHOWDHARY V.R., et al.: Autoimmune hepatitis: A review of current diagnosis and treatment. Hepat. Res. Treat., 390916, 2011. 
11- ABDURRAHMAN A., ALJUMAH A.A., HAMAD A., KHALED A., et al.: Clinical Presentation, Treatment Outcome and Predictors of Severity in Autoimmune Hepatitis: A Retrospective, Multicenter Experience. Journal of Gastroenterology and Hepatology Research, Vol. 5, No. 4, 2016.

12- FALLATAH H., AKBAR H.O. and QARI Y.A.: Autoimmune hepatitis: Single-center experience of clinical presentation, response to treatment and prognosis in Saudi Arabia. Saudi J. Gastroenterol., 16: 95-9, 2010.

13- SOOK-HYANG JEONG: Current epidemiology and clinical characteristics of autoimmune liver diseases in South Korea, Clin. Mol. Hepatol., Volume 24 (1), 2018.
14- VAN GERVEN N.M.1, VERWER B.J., WITTE B.I., VAN ERPECUM K.J., VAN BUUREN H.R., et al.: (Oct.) Epidemiology and clinical characteristics of autoimmune hepatitis in the Netherlands. Scand J. Gastroenterol., 49 (10): 1245-54, 2014.

15-KIM B.H., KIM Y.J., JEONG S.H., TAK W.Y., AHN S.H., LEE Y.J., JUNG E.U., et al.: Clinical features of autoimmune hepatitis and comparison of two diagnostic criteria in Korea: A nationwide, multicenter study. J. Gastroenterol. Hepatol., 28: 128-34, 2013.

16- PANAYI V., FROUD O.J., VINE L., LAURENT P., WOOLSON K.L., HUNTER J.G., et al.: The natural history of autoimmune hepatitis presenting with jaundice. Eur. J. Gastroenterol. Hepatol., 26: 640-5, 2014.

\title{
تكرار وظهور إلتهاب الكبد المناعى الذاتى وثوع الإضداد الذادئ الذئية،

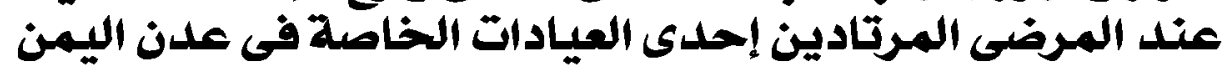

\author{
إلتهاب الكبد المناعى الذاتى مرض معقد ويمثل تحدى فى التثخيص والعلاج نتيجة التنوع فى المظاهر السريرية، ويعتبر نادر نسبيا، \\ ويصيب بلرجة رئيسية الإناث. \\ الآهداف: تهدف هذه الدراسة لوصف ظهود إلتهاب الكبد المناعي الذاتى وتكراره، ونوع الآضداد الذاتية، عند المرضى المرتادين إحدى \\ العيادات الخاصة في علن اليمن.

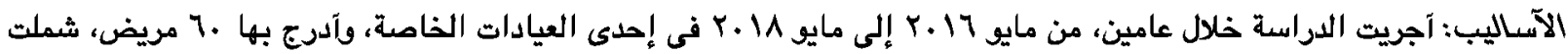

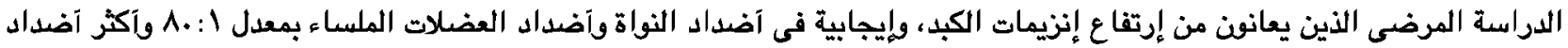

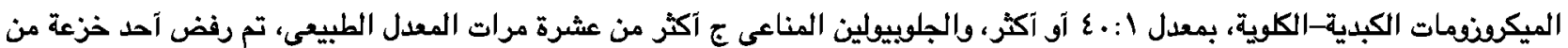 \\ الكبد من كل المرضى.
}

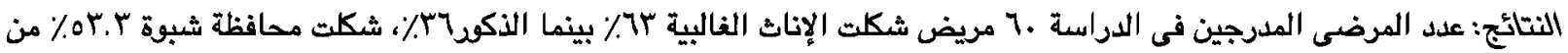

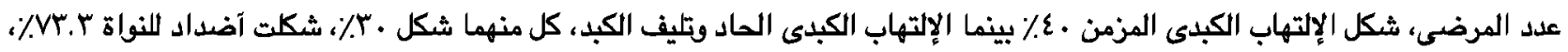
بينما آضداد العضلات الملساء 7.

الخلاصة: خلصت الدراسة إن الإلتهاب الكبدى المناعى الذاتى ظهره وتكراره ونوع الآضداد لا يختف عن الدراسات التى آجريت فى الدول الآخرى. 